\title{
Environmental Challenges on Leaf Spot and Blight of Sunflower (Helianthus annuus L.)
}

\author{
Ranjan Kumar Jena ${ }^{1}$, Nimai Charan Swain ${ }^{1}$, Shubhendu Kumar Behera ${ }^{1}$, \\ Nitish Kumar Jena ${ }^{2 *}$, Manasranjan Rout ${ }^{1}$, Debadatta Bibhudendra Pratap ${ }^{1}$, \\ Angshuman Mohapatra ${ }^{3}$ and Bitish Kumar Nayak ${ }^{3}$
}
${ }^{1}$ Deparment of Plant Pathology, ${ }^{2}$ Deparment of Horticulture, ${ }^{3}$ Deparment of Soil science, Institute of Agricultural Sciences, Siksha 'O' Anusandhan (Deemed to be University), Bhubaneswar, Odisha, India

*Corresponding author

\section{A B S T R A C T}

\begin{tabular}{|l|}
\hline Ke y w o r d s \\
Symptomatology, \\
$\begin{array}{l}\text { Defoliation, } \\
\text { Alternaria } \\
\text { helianthi, } \mathrm{pH}, \\
\text { Temperature, } \\
\text { Kharif season, } \\
\text { Rabi season }\end{array}$ \\
\hline Article Info \\
\hline $\begin{array}{l}\text { Accepted: } \\
22 \text { June } 2020 \\
\text { Available } \\
\text { Online: } \\
\text { 10 July } 2020\end{array}$ \\
\hline
\end{tabular}

\section{Introduction}

Sunflower (Helianthus annuus L.) is an important major oilseed crop ranks next to groundnut and soybean at global level. It is cultivated in India over an area of 21.62 lakh ha with a production of 12.24 lakh tonnes in different states like Karnataka, Maharashtra, Bihar, Andhra Pradesh, Haryana and Tamil
Sunflower is an important major oilseed crop ranks next to groundnut and soybean at global level. It belongs to the family Asteraceae and mostly infected by several fungal, bacterial and viral diseases among which leaf spot and blight caused by Alternaria helianthi was considered as one of the most destructive diseases in the sunflower growing areas. An experiment was studied to determine the disease incidence and intensity of the disease in both Kharif and Rabi season (2018-19) by observing the plant raised in field. Attempt was made to evaluate the effect of different range of $\mathrm{pH}$ and temperature on growth of the fungus and calculated under field condition in both Kharif and Rabi season. The results obtained from the present investigation indicate that the incidence of the disease and its intensity was found more during Rabi season than in Kharif under field condition which may be attributed to suitable environment and favourable soil conditions. Maximum dry weight growth of the fungus was observed at $\mathrm{pH} 6.0$ followed by $\mathrm{pH} 5.0$ and temperature at $30^{\circ} \mathrm{C}-35^{\circ} \mathrm{C}$. The above parameters should be considered while growing sunflower in field condition along with other protection measures to grow disease free sunflower crop with maximum yield and good quality seed. 
Nishihara is a serious threat to successful cultivation to the crop worldwide. The crop is affected by biotic and abiotic stresses. Among the several biotic factors, susceptibility to fungal diseases is one of the major constraints for successful sunflower production. The major diseases of sunflower in India are leaf blight (Alternaria helianthi), wilt (Sclerotium rolfsi) and root rot caused by Rhizoctonia solani and Macrophomina phaseolina. Gulya and Masirevie (1991) listed 80 pathogens occurring on sunflower. Among this leaf blight caused by Alternaria helianthi (Hansf.) Tubaki and Nishihara has been considered as potentially destructive disease in many parts of the sunflower growing countries around the world (Mahipal, S., Ghemawat (1989)).

The first report of disease was recorded in India by Narain and Saksena (1973) and Kolte and Mukhopadhyay (1973) from Uttar Pradesh and subsequently, by Anil kumar et al., (1974) from Karnataka. In Karnataka, the disease occurred in epidemic form in 1987, with a disease incidence of 95 to $100 \%$ (Hiremath et al., 1990). Yield loss may occur through reduced head diameters, number of seeds per head, and oil content or quality. $A$. helianthi can cause leaf and stem lesions, seedling blight and head rot. It has been reported to reduce seed and oil yield up to $84 \%$ and $33 \%, \quad$ respectively (Balasubrahmanyam and Kolte, 1980, Kolte, 1985).

The pathogen survives between sunflower crops in and on infested crop debris, as a pathogen of safflower and cocklebur, and on seed. Hot weather and frequent rain during the vegetative growth stage of the crop accelerate the disease intensity. Disease development is favoured by $25-27{ }^{0} \mathrm{C}$ temperature with at least 12 hours of wet foliage is reported to spread rapidly during the rainy season (Basappa and Santha Lakshmi Prasad, 2005).
Sunflower is an important major oil seed crop grown in different region in Odisha since a long period of time. The conducive weather conditions prevailing in different parts of Odisha become the prime and favourable factors for development and severity of leaf spot and blight disease of sunflower caused by Alternaria sp. Considering the fact effort was made to study the disease under local field condition (Bhubaneswar) both in Kharif and Rabi season 2018-2019. Attempt was also made to test the impact of $\mathrm{pH}$ and temperature on dry weight growth of the fungus under in vitro condition.

\section{Materials and Methods}

Study of disease symptoms under field condition, Isolation of the pathogen and its identification

The pathogen Alternaria helianthi was isolated from the infected leaf sample showing typical symptoms of the disease. The disease samples were washed with distilled water to remove the foreign materials. A small disease portion $(4-5 \mathrm{~mm})$ of leaf along with healthy portion from the periphery were cut into pieces and surface sterilized with sodium hypochlorite $(0.1 \%)$ solution for 2 minutes followed by subsequent washing in sterile distilled water for 3 times to remove residues of sodium hypochlorite from cut pieces. Then the diseased cut pieces were aseptically transferred in the center of PDA plates as well as PDA slant. They were incubated inside a B.O.D incubator at temperature $25 \pm 1{ }^{0} \mathrm{C}$ for $7-10$ days. The pure culture of the fungus was obtained by further growing the culture and following hyphal tip culture under aseptic conditions (Rangaswamy, 1972). The fungus was identified by observing the morphological and cultural characteristics in PDA slant as well as plate. 


\section{Weather parameters during Kharif and Rabi 2018-19}

Meteorological parameters in response to disease incidence

In order to study the relationship of meteorological parameters on the natural occurrence of disease (leaf spot and blight) by Alternaria helianthi in sunflower plant. The observations were recorded from July to October 2018 as Kharif crop and December (2018) to March 2019 as Rabi crop under field condition at experimental plot of instructional farm, SOADU, Bhubaneswar. The weather parameters like maximum and minimum temperature $\left({ }^{0} \mathrm{C}\right)$, maximum and minimum $\mathrm{RH}(\%)$, rainfall $(\mathrm{mm})$ and bright sunshine hours (hr) were co-related with sunflower leaf spot/blight disease incidence. A standard scale (0-9) basing on the intensity of the disease appearance on sunflower leaves was recorded through visual estimation. Percent disease incidence was calculated by using the formulae as mentioned below

\begin{tabular}{|c|c|}
\hline Incidence & $(\%)$ \\
\hline Numb & ted \\
\hline
\end{tabular}

PDI $=\frac{\text { Total numerical rating }}{\text { Total number of units examined }} \times 100$

For recording the disease incidence 100 number of sunflower plants were grown in instructional farm $(4 \times 4 \mathrm{~m})$ in each season (Kharif and Rabi). The percentage of plant infected was calculated basing on their number and the disease intensity was recorded in (0-9) scale as per the formula already given (Mayee and Dater, 1986).

Standard meteorological parameters were obtained from the Meteorological observatory, Department of AgroMeteorology, SOADU, Bhubaneswar.
In vitro evaluation of $\mathrm{pH}$ on growth of fungus

Alternaria helianthi was isolated from the infected sunflower plant and maintained as pure culture on PDA plate. 10 days old culture was used for testing the growth of the fungus at different $\mathrm{pH}$. The PD broth to be used for the growth of test fungus adjusted in different ranges of $\mathrm{pH}$ starting from 2.0 to 8.0 with help of Philips precision $\mathrm{pH}$ meter by adding $0.1 \mathrm{~N}$ acid (HCL) and $0.1 \mathrm{~N}$ alkali $(\mathrm{NaOH})$. Three replication made for each treatment (10 days old). The fresh growth of the fungus maintained in PDA plate $(7 \mathrm{~mm})$ was cut and inoculated in PD broth maintained at different $\mathrm{pH}$ ranges.

The final growth was obtained in the PD broth at different $\mathrm{pH}$ finally filtered through whatman filter paper and which was properly dried in hot air oven at temperature $60-80^{\circ} \mathrm{c}$ continuously for 2-3 days. The final dry weight of the fungal growth with filter paper was taken and deducted from the weight of the dry filter paper used for the experiment. The net weight was recorded and mean dry weight growth of the fungus was calculated for each range of $\mathrm{pH}$.

\section{Effect of temperature on growth of fungus under in-vitro condition}

The effect of temperature on dry weight growth of the fungus was done in different ranges like $10,15,20,25,30,35$ and $40^{\circ} \mathrm{C} .7$ days old fresh culture of the fungus $(7 \mathrm{~mm})$ was used and inoculated to sterilized conical flask containing PD broth.

After inoculations the flasks were kept in B.O.D incubator adjusted in different range of temperature like 10,15,20,25,30, 35 and $40^{\circ} \mathrm{C}$. For each range of temperature three replications were maintained. The growth was obtained in the PD broth at different ranges of temperature finally filtered and properly dried 
in hot air oven at temperature $60-80^{\circ} \mathrm{c}$ continuously for 2-3 days. The final dry weight of the fungal growth was recorded and deducted from the weight of dry filter paper used for the experiment. The net weight was recorded and mean dry weight growth of the fungus was calculated.

\section{Results and Discussion}

\section{Symptomatology}

Sunflower plant were found to be affected by leaf spot and blight disease in instructional farm during the year 2018-19 in Kharif and Rabi season.

The disease symptoms appeared in form of dark brown to black spot measuring 0.2 to 0.5 $\mathrm{mm}$ in diameter. The spots appeared circular, oval, and sometimes oblong and irregular in shape surrounded by yellowish halo.

The symptoms gradually started spreading from the lower leaves to upper leaves and subsequently to stem, branches and flower head. In advance stages of the disease the spots enlarged coalesced resulting the symptoms of blightening. The severity of the disease results stunting of plant growth, defoliation and poor head formation with infected seed (Plate-1). Although the disease symptoms of leaf spot and blight found more or less similar both in Kharif and Rabi but the intensity of the disease was found higher in Rabi (Plate-2 and Plate-3).

The symptoms of leaf spot and blight affecting sunflower was observed in India and abroad in different times by many scientist. The initial stage of the disease symptoms and subsequent development of disease resulting it's severity was also observed by scientist like Tubaki \& Nishihara, 1969; Narain and saksena, 1973; Kolte and Mukhopadhyay, 1973; Anil Kumar et al., 1974 and Vikas et al., 2010).

\section{Disease incidence in Kharif and Rabi}

Sunflower plants were raised in instructional farm (IAS) to observe and compare the disease incidence of leaf spot/blight in both Kharif and Rabi season. The result on disease incidence on leaf spot/blight (Table-2) showed that all the plants got infected by the disease in both Kharif and Rabi (2018-19).

The disease incidence in Kharif season found within 5-30\% which was found more in Rabi varying from $15-40 \%$ (Plate-2 and Plate-3). While studying the disease intensity of the infected plant it was observed that the plants raised in Kharif season showed lower disease intensity (40-60\%) which was found higher in Rabi i.e. 60-80\% (Plate-3).

The symptoms of leaf spot/blight observed in sunflower plant both in Kharif and Rabi were apparently similar only except variation in disease intensity.

The higher percentage of plant infection and disease intensity in Rabi season may be attributed to high inoculum load in soil and air and the favorable climatic conditions like temperature, relative humidity and soil moisture prevailing during that period of time.

The optimum temperature $\left(\max .32 .5^{\circ} \mathrm{C}\right.$, min. $25^{\circ} \mathrm{C}$ ), Relative humidity (74-94) and Rainfall $(420 \mathrm{~mm})$ and adequate soil moisture (Table3 and Table-4) during Rabi season probably favored higher disease incidence in sunflower. Present finding was supported by scientist Mayee (1994) and Mayee and Wankhede (1997). 
Table.1 Showing scale and disease intensity of $A$. helianthi

\begin{tabular}{|c|c|}
\hline Numerical rating & Description \\
\hline 0 & No symptoms on leaf \\
\hline 1 & Small, irregular brown spots covering $1 \%$ or less of the leaf area \\
\hline 3 & $\begin{array}{l}\text { Small, irregular, brown spots with concentric rings covering } 1-10 \% \text { of the } \\
\text { leaf area. }\end{array}$ \\
\hline 5 & $\begin{array}{l}\text { Lesions enlarging, irregular, brown with concentric rings covering } 11- \\
25 \% \text { of the leaf area. }\end{array}$ \\
\hline 7 & $\begin{array}{l}\text { Lesions coalesce to form irregular brown patches with concentric rings } \\
\text { covering } 26-50 \% \text { of the leaf area. Lesions also on stem and petioles. }\end{array}$ \\
\hline 9 & $\begin{array}{l}\text { Lesions coalescing to form irregular, dark brown patches with concentric } \\
\text { rings covering } 51 \% \text { or more of the leaf area. Lesions seen on the stem and } \\
\text { petiole }\end{array}$ \\
\hline
\end{tabular}

Table.2 Disease incidence and degree of disease intensity of Leaf spot/blight of sunflower both in Kharif and Rabi 2018-19

\begin{tabular}{|c|c|c|c|}
\hline Treatments & Total no. of plants & $\begin{array}{c}\text { Total no. of } \\
\text { plantinfected(\%) }\end{array}$ & $\begin{array}{c}\text { Disease intensity } \\
(\%) \text { of the infected } \\
\text { plants }\end{array}$ \\
\hline Plant sown in kharif & 100 & $10 \%$ & + \\
\hline Plant sown in Rabi & & $38 \%$ & ++ \\
\hline & 100 & $52 \%$ & +++ \\
\hline & & $12 \%$ & + \\
\hline & & $25 \%$ & ++ \\
\hline
\end{tabular}

Table.3 Standard meteorological parameters during Kharif 2018

\begin{tabular}{|c|c|c|c|c|c|c|}
\hline Month & Year & \multicolumn{2}{|c|}{ Temperature ( c) } & \multirow{2}{*}{ Rainfall(mm) } & \multicolumn{2}{c|}{ Relative Humidity } \\
\cline { 3 - 4 } & & Max. & Min. & & 7hr & 14hr \\
\hline July & 2018 & 32.5 & 26.0 & 639.2 & 94 & 79 \\
\hline Aug & 2018 & 32.2 & 25.9 & 414.2 & 93 & 77 \\
\hline Sept & 2018 & 32.6 & 25.2 & 390.4 & 94 & 74 \\
\hline Oct & 2018 & 32.5 & 22.8 & 236.8 & 94 & 60 \\
\hline
\end{tabular}

Table.4 Standard meteorological parameters during Rabi 2018-19

\begin{tabular}{|c|c|c|c|c|c|c|}
\hline \multirow{2}{*}{ Month } & Year & \multicolumn{2}{|c|}{ Temperature( $\mathbf{c})$} & \multirow{2}{*}{ Rainfall(mm) } & \multicolumn{2}{|c|}{ Relative Humidity } \\
\cline { 3 - 4 } & & Max. & Min. & & $7 \mathbf{7 h r}$ & $\mathbf{1 4 h r}$ \\
\hline Dec & 2018 & 27.2 & 14.1 & 11.1 & 89 & 45 \\
\hline Jan & 2019 & 28.5 & 13.0 & 0.0 & 95 & 38 \\
\hline Feb & 2019 & 32.9 & 17.0 & 24.6 & 94 & 35 \\
\hline Mar & 2019 & 35.2 & 23.2 & 7.1 & 92 & 46 \\
\hline
\end{tabular}


Table.5 Effect of $\mathrm{pH}$ on dry weight growth of the fungus A. helianthi

\begin{tabular}{|c|c|c|}
\hline Treatments & pH & Mean dry weight growth(mg) \\
\hline T1 & 2.0 & 4.00 \\
\hline T2 & 3.0 & 116.00 \\
\hline T3 & 4.0 & 125.00 \\
\hline T4 & 5.0 & 176.33 \\
\hline T5 & 6.0 & 228.00 \\
\hline T6 & 7.0 & 134.67 \\
\hline T7 & 8.0 & 132.67 \\
\hline & SE $(m)+$ & 1.25 \\
\hline & CD $(0.05)$ & 3.86 \\
\hline
\end{tabular}

Table.6 Effect of temperature on dry weight growth of the fungus A. helianthi

\begin{tabular}{|c|c|c|}
\hline Treatments & Temperature( $\mathbf{C})$ & Mean dry weight growth(mg) \\
\hline $\mathbf{T}_{\mathbf{1}}$ & 10 & 366.00 \\
\hline $\mathbf{T}_{\mathbf{2}}$ & 15 & 682.00 \\
\hline $\mathbf{T}_{\mathbf{3}}$ & 20 & 893.33 \\
\hline $\mathbf{T}_{\mathbf{4}}$ & 25 & 1272.00 \\
\hline $\mathbf{T}_{\mathbf{5}}$ & 30 & 1558.00 \\
\hline $\mathbf{T}_{\mathbf{6}}$ & 35 & 1522.33 \\
\hline $\mathbf{T}_{\mathbf{7}}$ & 40 & 1015.00 \\
\hline & $\mathrm{SE}(\mathrm{m}) \pm$ & 1.35 \\
\hline & $\mathrm{CD}(0.05)$ & 4.17 \\
\hline
\end{tabular}

Fig.1 Effect of $\mathrm{pH}$ on dry weight growth of the A. helianthi
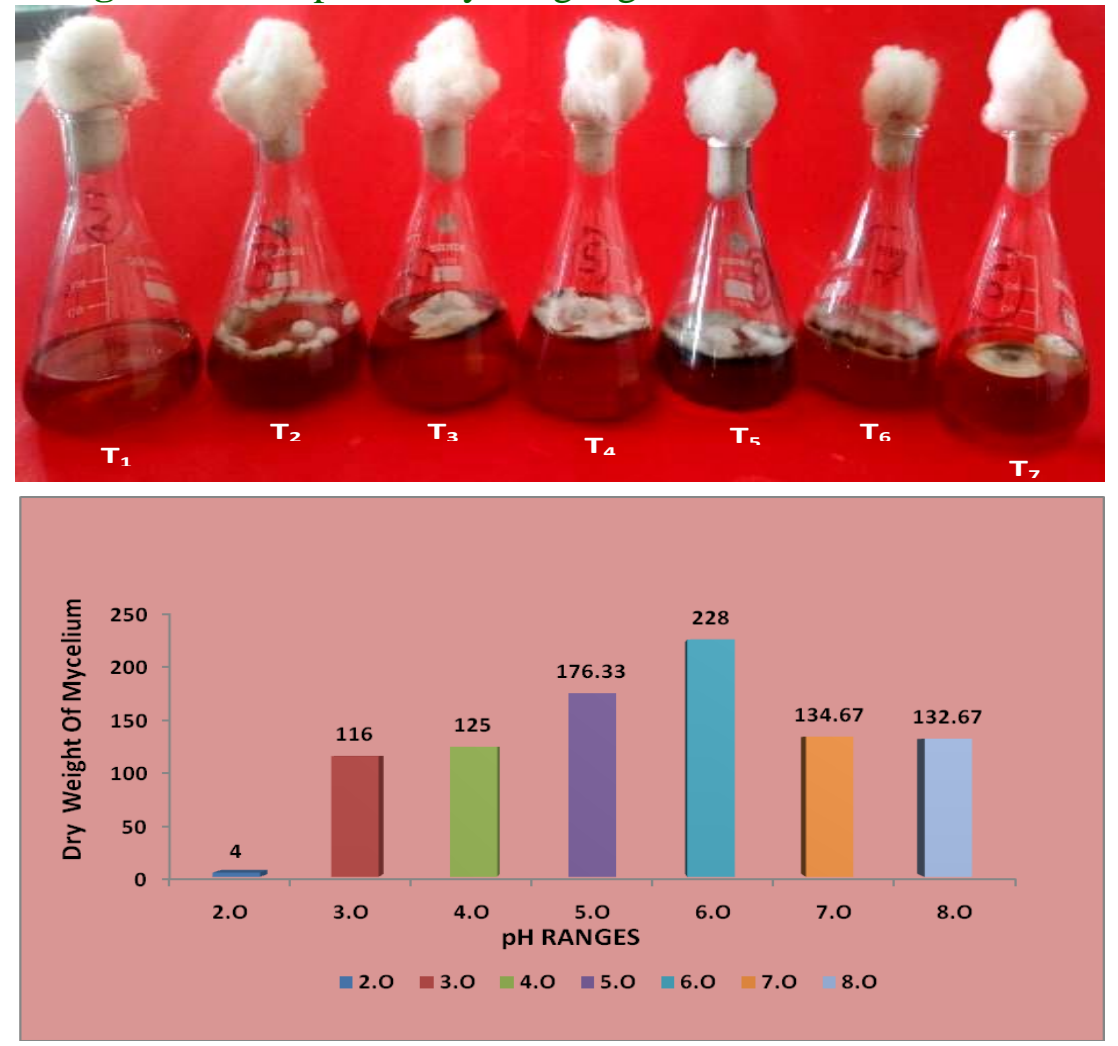
Fig.2 Effect of Temperature on dry weight growth of the A. Helianthi
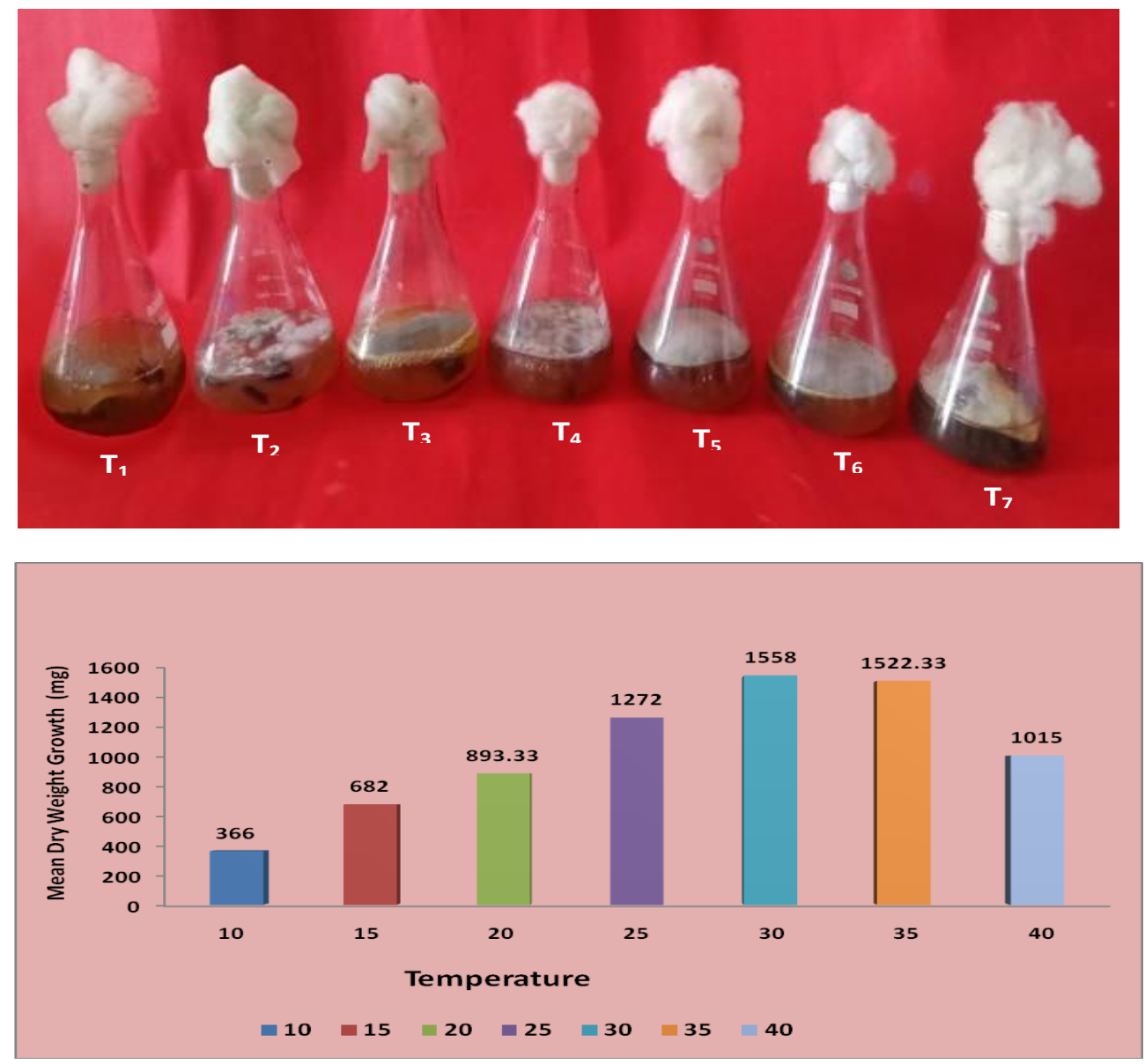

Plate.1 Leaf and head infection showing symptoms under field condition
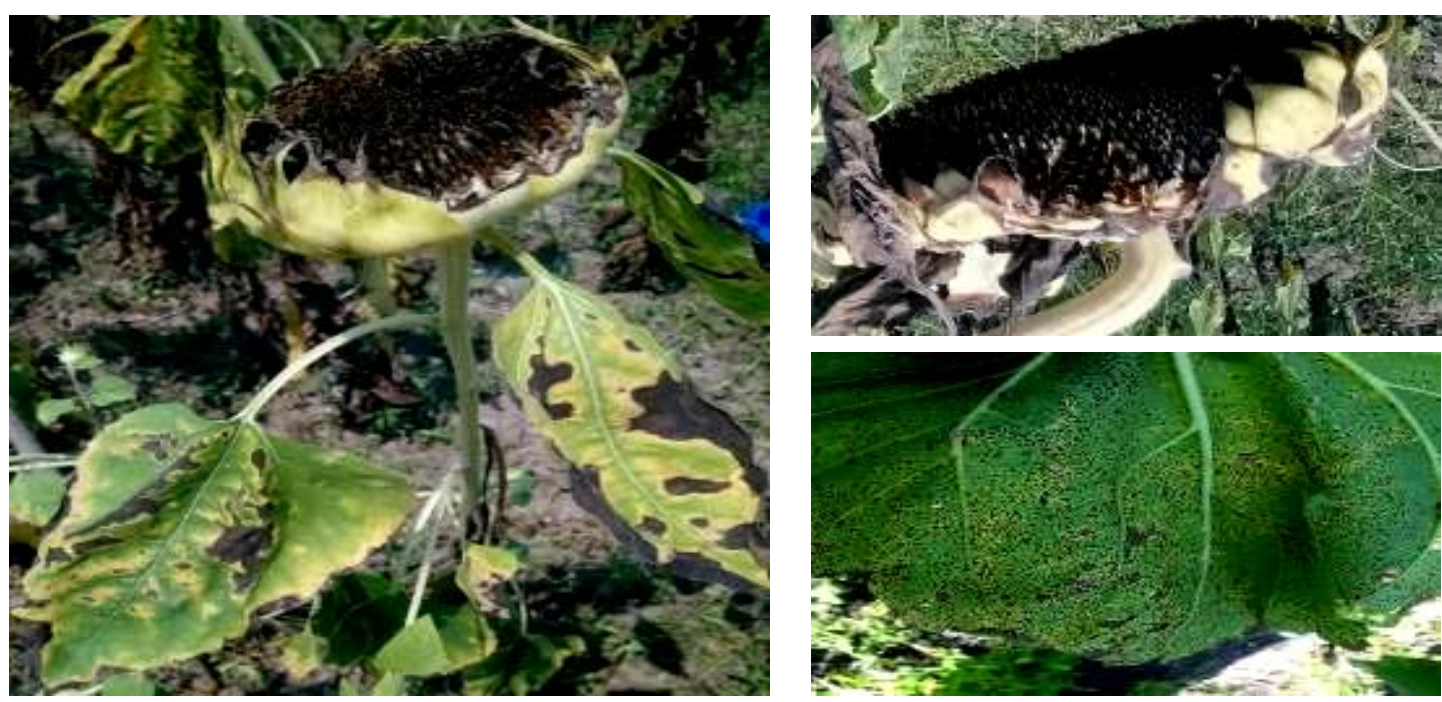
Plate.2 Disease symptom of leaf spot/blight of sunflower in Kharif
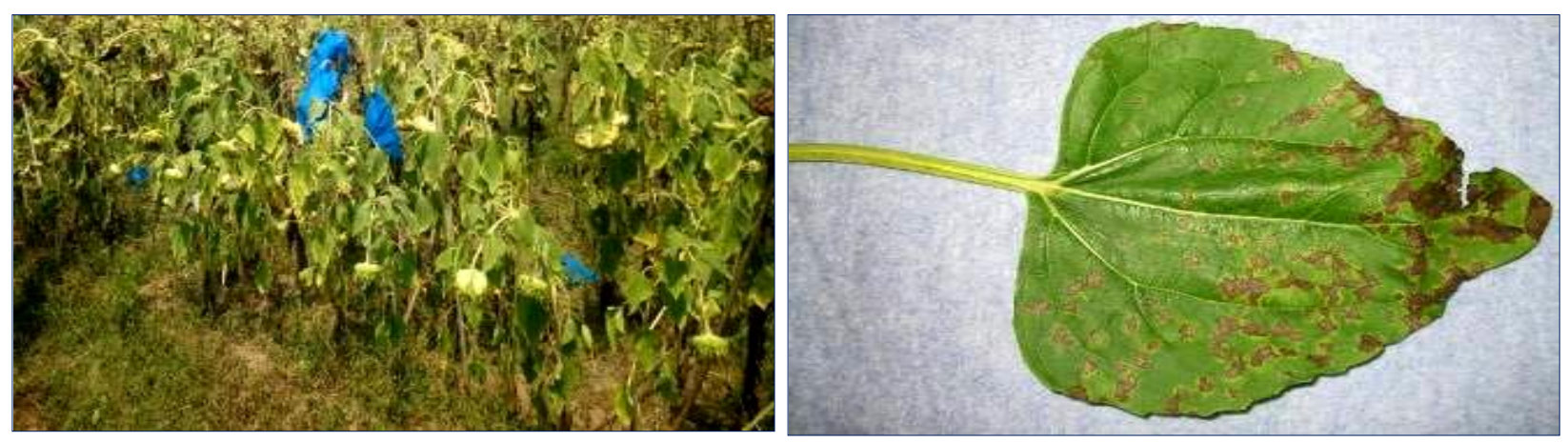

Plate.3 Disease symptom of leaf spot/blight of sunflower in Rabi

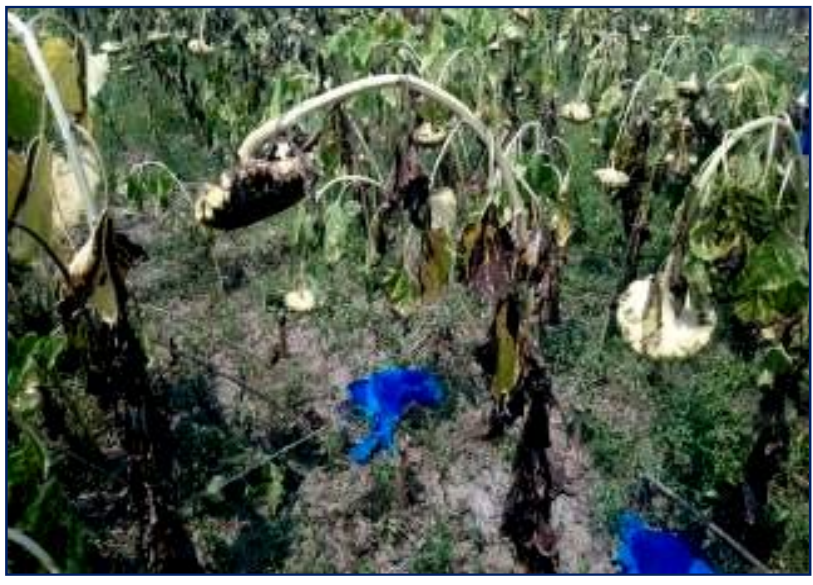

\section{Effect of $\mathbf{p H}$}

The experimental finding of effect of $\mathrm{pH}$ on dry weight growth of the fungus it was observed that neutral $\mathrm{pH} 6.0$ produced maximum growth $(228 \mathrm{mg})$ followed by $\mathrm{pH}$ 5.0 (Table-5) (Plate-4). While the growth was declined in higher $\mathrm{pH}$ (alkaline) i.e. 7.0 and 8.0 and it was found still less in acidic range i.e. 2.0, 3.0 and 4.0 and minimum in $\mathrm{pH} 2.0$ (4mg) (Fig.-1). The observation of effect of $\mathrm{pH}$ on growth of $A$. helianthi was also studied by many scientist and supported the present finding [Jash et al.(2003), Ramjegathesh and Ebenezar (2012)].

\section{Effect of temperature on dry weight growth of A. helianthi}

The experimental result (Table-6) (Plate-5)

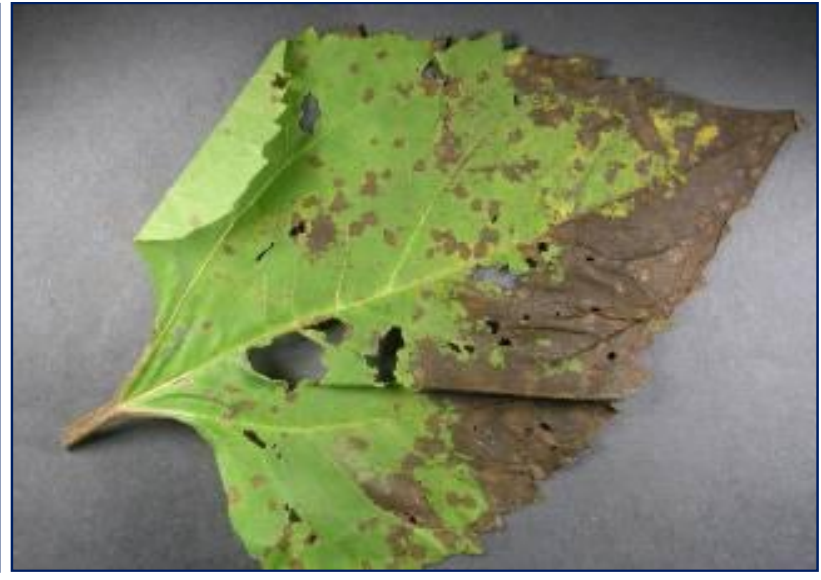

revealed that highest dry weight growth of fungus $A$. helianthi was obtained at temperature $30^{\circ} \mathrm{C}$ showing $1558.0 \mathrm{mg}$ followed by temperature $35^{\circ} \mathrm{C}$ showing the dry weight growth $1522.33 \mathrm{mg}$ and they were significantly superior to other treatment. The dry weight growth of the fungus comparatively less in $25^{\circ} \mathrm{C}$ i.e. $1272 \mathrm{mg}$ and the same trend was observed minimum (366.0 $\mathrm{mg})$ at $10^{\circ} \mathrm{C}$ which gradually enhanced with increasing range of temperature and observed maximum within $30-35^{\circ} \mathrm{C}$ but beyond that it again started declining (Fig.-2). The experimental result was found in agreement with the finding of many scientists like Prathibha et al., (2008) and Hubbali et al., (2010).

The salient findings of the present study clearly indicates incidence of leaf spot and 
blight disease symptoms developed in sunflower plant remained more or less similar both in Kharif and Rabi (2018-19). However the disease intensity was found higher in Rabi which may be attributed to the climatic condition and soil moisture and inoculum load in crop rhizosphere.

Considering the rate of multiplication and growth of the test fungus under in-vitro condition, the result of the present experiment reveals that maximum dry weight of the fungus obtained in neutral $\mathrm{pH}$ i.e. 5.0-6.0 which was declined in either acidic or alkaline range. Most favourable range of temperature encouraging maximum growth of fungus under in-vitro condition was found within 30$35^{\circ} \mathrm{C}$. So climatic condition with above favourable range of temperature and soil $\mathrm{pH}$ may affect the crop with higher disease incidence lowering yield and seed quality. Therefore, attention should be paid while taking the sunflower crop in a particular area considering the above environmental factors in order to increasing the yield and quality of the crop.

\section{References}

Anil Kumar TB, Urs SD, Seshadri VS and Hedge RK.1974. Alternaria leaf spot of sunflower, Curr. Sci., 43: 93-94.

Basappa H and Santha Lakshmi Prasad M. 2005. Alternaria leaf blight/leaf spot. In: Hegde DM (ed.), Insect Pests and Diseases of Sunflower and their Management, Hyderabad, Directorate of Oilseeds Research,: 30-33.

Bhutta AR. 1998. Biological studies on some fungi associated with sunflower in Pakistan [PhD thesis], Pakistan: Sindh Agriculture University.

Gulya JJ and Masireview. 1991. Common names for the plant diseases of sunflower (Helianthus annuus L.) and Jerusalem artichoke (Helianthus tuberosa L.). Plant Disease, 75: 30.

Hiremath PC, Kulkami MS and Lokesh MS. 1990. An epiphytotic of Alternaria blight of sunflower in Karnataka. Karnataka J. Agrie. Sei. 3 (3-4): 277278

Hubballi M, Nakkeeran S, Raguchander T, Ananad T and Samiyappam R. 2010. Effect of environmental conditions on growth of Alternaria alternata causing leaf blight of noni, World J. Agricultural Sciences, 6: 171-177.

Jash. 2003. Effect of different culture media on growth and sporulation of A. zinnia, causing leaf blight of marigold, Environ. \& Ecol, 21(2): 321-325.

Kolte M and Mukhopadhyay HS. 1973. Location of Alternaria spp. in sunflower seeds, Plant Dis. Res., 5: 203-204.

Mahipal, S., Ghemawat, B. K. S., \& Agrawat, J. M. (1989). Yield losses in sunflower due to Alternaria helianthi (Hansf.) Tubaki and Nishihara. Archives of Phytopathology and Plant Protection, 25, 541-544.

Mayee CD and Dater CV. 1986. A Major disease and their management in sunflower current states and research priorities current trends in life science 20: 179-184, Today and Tomorrow pointers, New Delhi.

Mayee CD. 1994. A Major disease and their management in sunflower current states and research priorities current trends in life science 20: 179-184, Today and Tomorrow pointers, New Delhi.

Narain U and Saksena SW. 1973. Occurence of Alternaria leaf spot on sunflowcr in India, Indian J. Mycology and Plant Pathol. 3: 115116.

Prathibha VM, Nanjegowda D and Nagaruju N. 2008. Effect of temperature and $\mathrm{pH}$ on the growth of different isolates of Alternaria helianthi (Hansf.) Tubaki and Nishihara on sunflower, Mysore 
Journal of Agricultural Sciences. 42(1):139-142

Ramaswamy R.1972. control of rust and Alternaria blight of sunflower, Madras Agric, J., 63: 401-402.

Ramjegathesh and Ebenezar.2012. Morphological and physiological characters of Alternaria alternata causing leaf blight disease of onion, Internat. J. Pl. Pathol., 3 (2): 34-44.
Tubaki K and Nishihara N. 1969. A. helianthi (Hansf) cumb Nov., Trans Br. Mycol Soc., 53: 147.

Vikas V. Patel, Singh CP and Mishra US. 2010. Symptomatological studies on leaf blight of sunflower caused by Alternaria helianthi in Rohilkhand, Adv. Biores, 1(1): 97-100.

\section{How to cite this article:}

Ranjan Kumar Jena, Nimai Charan Swain, Shubhendu Kumar Behera, Nitish kumar Jena, Manasranjan Rout, Debadatta Bibhudendra Pratap, Angshuman Mohapatra and Bitish Kumar Nayak. 2020. Environmental Challenges on Leaf Spot and Blight of Sunflower (Helianthus annuus L.). Int.J.Curr.Microbiol.App.Sci. 9(07): 2756-2765.

doi: https://doi.org/10.20546/ijcmas.2020.907.325 